overdrawn. The short and inadequate section on sea level changes shows no acquaintance with the work, between 1974 and 1982, of the International Geologic Correlation Project No.61, on sea level change in the last 15,000 years. Similarly the claim that it will become the standard work looks somewhat exaggerated in the light of a reference list confined solely to textbooks. In short, the book has some merit as an introduction to the subject but is not for advanced students and research workers.

The last of this trilogy, Environmental Systems, is a modest approach to the very

IMAGE
UNAVAILABLE
FOR
COPYRIGHT
REASONS

Subject for the geomorphologist - the Grand Canyon, drawn c. 1880 by William H. Holmes.

broad subject of "the environment". As an introductory text, which it claims to be, it has much to offer. Unlike Chorley et al. the authors do not set out to embrace, or even to reconcile, all approaches to their subject matter but concentrate firmly on the single methodology of their title. In this the book is very largely successful. A careful factual exposition is supported by frequent references to source material, by detailed suggestions for further reading and by a bibliography of 350 journal references. It is a little disappointing that Part $\mathrm{C}$ does not include any treatment of coastal environments - the book's aim to promote "an understanding of Man's terrestrial environment" surely cannot be entirely achieved if it ignores a part of it where such a large number of people live and work. Despite this shortcoming this is a successful book and one which can be recommended to the readership at which it aims.

The strength of interest in "the environment" is shown by the steady flow of publications in this general field at all levels. Occasionally an outstanding book in a specialized part of the subject appears and tends to overshadow other worthwhile contributions. Geomorphology by Chorley, Schumm and Sugden is such a work. Still, the other volumes reviewed here also have their strengths and will be of value to somewhat different readerships. $\square$

C. Kidson is Emeritus Professor of Physical Geography at the University College of Wales, Aberystwyth.

\section{Devonian review}

\section{Bruce Sellwood}

Aspects of a Stratigraphic System: The Devonian.

By D.L. Dineley.

Macmillan, London: 1984. Pp.223. Hbk $£ 20$; pbk $£ 9.95$.

THE Devonian Period spans some 48 million years (408-360 Myr) and was originally established, in Devon, as the Devonian System by the entrepreneurial stratigraphic approach of Sedgwick and Murchison in 1839. David Dineley, who has devoted many years to research on the Devonian and its fish faunas, has written this book to illustrate, he says, the ways in which the different disciplines within geology help our understanding of how things were 360 million years ago. He claims that it is aimed at the "interested" but "not very advanced student of historical geology".

The book doesn't really provide a source on regional Devonian geology (though in fairness one should say that it doesn't set out to do so); thus it cannot be used in the same way as Arkell's masterly descriptive account, Jurassic Geology of the World (Oliver and Boyd, 1956). Neither does it provide an ideas approach to a system comparable with that of Hallam's Jurassic Environments (Cambridge University Press, 1975). Instead it falls somewhere in between.

The introduction attempts to justify use of the Devonian as a vehicle for the book "because it is there", an argument that also recurs in subsequent chapters on the materials of stratigraphy, and stratigraphy and the world tectonic model. In the latter, plate tectonic models are extensively adopt-

ed from the literature, although being considered "crude means of solving problems in crustal history"'. The next chapter ("Time in Question") shows how stratigraphic correlation is achieved, while Chapter 5 deals with biostratigraphy and reviews the various groups of organisms found in Devonian rocks and their use in correlation.

The following four chapters deal with Devonian facies: Old Red Sandstone; paralic facies (including some carbonates); carbonates and evaporites; and deep-water suites. Each begins with a generalized global review before giving brief accounts of individual areas (Arctic Canada, western Europe, the Russian Platform, AltaiSayan, east Asia and so on). Many maps are included (though only a single isopachyte map occurs in the whole book), but relatively few stratigraphic sections. This is a pity in view of the fact that, after correlation, successful stratigraphic interpretation rests on the details of sequence evaluation.

Finally, Dineley considers Devonian geography, particularly covering recent work on possible continental dispositions, facies and the oceanographic implications. Climatic changes are reviewed and notions of meteorite impact speculated upon.

I'm unsure about the readership for this book. It cannot really be for "interested" students, because they will get lost in the sections on biostratigraphy; and it won't be for the specialist Devonian workers because this is a broad scale review. Still, it should be taken up by university libraries where it will be a useful student text for the few sessions normally spent on Devonian geology.

Bruce Sellwood is a Lecturer in Geology at the University of Reading.

\section{Earth through time}

\section{A. Hallam}

The History of the Earth's Crust.

By Don L. Eicher, A. Lee McAlester and Marcia L. Rottman.

Prentice-Hall: 1984. Pp.197. Hbk \$25.60, £23.30; pbk \$22.90, £20.85.

The Evolving Continents, 2nd Edn.

By Brian F. Windley.

Wiley: 1984. Pp.399. Hbk f25, \$24.95;

pbk £9.95, \$21.50.

IN THE current enthusiasm to understand more about geological processes in such diverse fields as sedimentation, rock deformation and volcanism, increasing use is made of mathematical modelling and modern laboratory techniques. This analytical approach remains somewhat sterile, however, if it fails to illuminate Earth history, which remains at the core of academic geology. Because the subject is so complex and involves synthesis of a diversity of rapidly growing research fields, satisfactory undergraduate textbooks are few and far between. As in other spheres of science the premium in research is on increased specialization and this inevitably influences what is taught in university courses.

The advent of the new book by Eicher, McAlester and Rottman is to be welcomed because, within its limitations, it copes very well with a difficult task. The principal limitation is one of brevity; the book forms part of a Prentice-Hall Earth Science series which is restricted to short, small-format books. The text is clearly written in plain, straightforward English and there are plenty of good illustrations. After an initial outline of stratigraphic principles and geochronology the authors deal with the Earth as a planet in a way more customary in physical geology texts, before devoting successive chapters to the Precambrian, Palaeozoic, Mesozoic and Cenozoic.

The writing is thoroughly up to date, whether dealing with subjects as different as Precambrian life and the cause of mass 